\title{
Persuasion and Pandemic
}

\author{
Grace Nana Amoakoa-Amoako \\ School of Law and Politics, Master Social Work, Zhejiang Normal University, China \\ ORCID number: 0000-0002-5229-9660
}

\begin{abstract}
The corona virus pandemic which hit our world in December, 2019 has been associated with a lot of anxiety, fear and panic. As experts realized the virus is widely spread through contact, a lot of restrictions on social contact were initiated into our world. The use of persuasion, directly or indirectly has been very important in stabilizing affairs and guiding individuals to abide by corona virus disease precautions. Persuasion can be referred to as an attempt to alter or modify an individual behavior, belief, values or attitude by using messages or communications without threat. Although, the internet and social media has helped people in adjusting to hard shifts of the pandemic, persuasion has been very instrumental in getting people to modify attitudes to adjust to Covid-19 shifts. Fortunately, nations are easing Covid 19 limitations, with some minimum amount of increase in Covid-19 cases and the introduction of Covid19 vaccine. The masses want to go back too quickly to their previous life; however, the pandemic is still lingering in our midst. This discourse employs concrete persuasion theories such as social judgment theory, cognitive dissonance theory and elaboration likelihood theory to reflect on how this lapse can be rectified. Then finally, elaborates on how persuasive messages can be utilized to prepare the world for a life beyond Covid-19. This will guide in the work of social scientist, stakeholders, epidemiologists, social thinkers and policy makers.
\end{abstract}

Keywords: persuasion, corona virus disease, pandemic, theories, attitude change, behaviors

\section{INTRODUCTION}

$I$ n, December, 2019, the coronavirus disease (SARS-Cov-2) hit the world emerging from Wuhan, China as an epidemic, within a short period of three months; the disease spread over large areas of the globe.(DImaio et al., 2020) The World Health Organization declared the disease a pandemic when it was reported that there were more than 118,000 cases and about 4,291 deaths in 114 countries. (Bavel et al., 2020)

This pandemic introduced a lot of hard shifts in the order of the world. It directly brought the normal of the world into a stand still. Many aspects of our social life such as schools, religious organization, clubs, and other institutions were closed down and lockdown by governments around the world to help mitigate the disease.

It was documented that the virus spread through contact (DImaio et al., 2020) and as such human physical movements were frowned upon and restricted. Some of the interesting shifts the disease brought about include social distancing, isolation, quarantine, wearing of nose mask compulsorily when going out among others.
The internet and its activities of Social media networks such as Skype, Zoom, Tik-tok, Facebook, and Instagram among others today has helped people develop coping strategies and find a way to connect with others virtually as governments put in measures to curb the infamous disease. There have been many researches in the medical sciences as well to come up with strategies to subdue the disease. Other works have been done by some social scientist to discuss, how the disease has affected human relations, attitude change, persuasion on social influence among others. (Bavel et al., 2020) (Harvard Magazine, 2013) However, there is still a gap on how persuasive techniques such as cognitive and affective have been employed to buckle corona virus on the planet. As well as, how these persuasive techniques can be employed to get people to stick to guidelines prescribes by Health services across countries and the World Health Organization until the pandemic becomes a thing of the past. Many communication mediums and techniques have been presented also; one for the focus of the study is on Persuasion. This paper stand in this gap to discuss influencing people behaviors and attitude towards mitigating the pandemic through persuasive techniques and applied theories.

Persuasion which can be referred to as communication without any form of threat used to modify values, beliefs and behaviors among individuals.(Wood, 2000) They help in forming and shaping attitudes in people. There are many theories that explain individuals shift in attitudes, persuasion is used to initiate attitudinal changes. Richard Perloff asserted five grounds why persuasion is extremely important today. Perloffs assertions include how the number of persuasive communications is growing, how these persuasive messages travels faster, institutionalization of persuasion, persuasive communication becoming more subtle and the complexity of persuasive communication.(Perloff, 2003) Persuasion is an attempt to get individuals be it their ages, race, class, or sexuality among others to behave in a manner or change an attitude and adopt another or embrace a point of view that the individual would not have considered or engaged in otherwise. As a result employing this technique to help extenuate the pandemic at stake is very important. This paper tries to dive into theories on persuasion and first walk down memory lane and discuss how persuasive techniques have been employed since the introduction of the disease. Further countries are easing lockdown protocols around the world and the introduction of Covid-19 vaccines it seems fears, panics and anxiety is calming among the masses, however the pandemic has not been completely eradicated, should we all quickly neglect existing protocols and go to our previous 
ways, another wave of the pandemic might knock the world down. The paper will discuss how persuasive theories can assist in outlining essential blueprints for keeping people in check in these times. This will be essential to guide policy makers to draft policies conditioned for a time like this which will be efficient and effective. Also, it will contribute to research in the social sciences and provide reference for future studies.

Global pandemics initiate the world with mainly chaos, breaking of conventional thinking, feeling, expressing and habits.(Campbell, 2020) When the pandemic first broke the anxiety and panic attached aided various health organizations and governments around the world to initiate ways of doings that people readily obeyed. However, as panic and anxiety is decreasing among people with time plus, with the ignition of vaccine for Covid 19 is also making some people complacent to consider going quickly to their ways of living before the end of the pandemic. The grave of this situation is timely for social science field to make a research work on how this situation can be catered for. This study targets to understand the research question: How persuasion techniques and theories contribute to mitigating the Covid-19 pandemic? The objective is to contribute literature on how persuasion can contribute its quota in mitigating the pandemic.

The assumptions of the study will be reached by means of reviewing peer reviewed published works from articles and journals based on the scope of the subject under study. Academic search engine bases such as Google Scholar, Scopus and Annual Review will be used to guide the course. Also, as the pandemic is a current problem, general news reportages and web pages on the discourse have been inculcated in the study and reviewed. The review process will be guided by coding to come out with pertinent strands and rid the study from any form of biases .(Saldaña, 2013)

\section{ASSUMPTIONS}

Persuasion serves as means of communication that intends to derive change in behavior or attitude. The current pandemic has brought the world to a stage where in order to mitigate or combat the disease and its effect the people of the world has be alienated from their previous interaction and ways of life. Medical health practitioners and experts plus governments have situated laid down rules and protocols that individual has to habituate and cultivate as part of their behaviors and ways of life. For instance, one has to wear the nose mask when going out, abiding by quarantine precautions, avid shaking of hands and hugging among others.

Consequently, in order to make people adopt new forms of behavior and attitude, it is necessary to attempt to understand 'why and what' causes an individual to make their choices and choose certain preferences. There exist many social science theories to explain why individuals make certain choices and choose certain preferences. A couple of these theories drawn many from the discourse of social psychology persuasion will be discussed later in this paper. However, one key theory that social thinkers have used over the decades in this discourse is the rational choice theory.

The rational theory may be applied in disciplines such as economics, psychology and philosophy among others. The theory has origin in the philosophical works of Adams Smith. $\mathrm{He}$ posits that the nature of human of self interest result from prosperity. This theme could also be drawn from the book 'the Leviathan" which was written by Thomas Hobbes. Most of this therefore influenced Adams Smith writing. (Burns \& Roszkowska, 2016)

Also, social thinkers such as George C. Homans, and James Coleman promoted the rational choice theory in the social sciences. These social theorists promoted that what drives social behavior is a rational calculation of an exchange of price and reward done by individuals in all situations. This helps explain why people may choose to interact or not interact with others in society. (Burns \& Roszkowska, 2016) This generally means that individuals are in control of their own choices and in making one they first weigh the advantages and disadvantages in it for them before deciding on a decision. In application to this study, in following precautions laid down to cater for the pandemic, individuals will weigh advantages in following them and the disadvantages in meeting them then draw their decisions. Therefore communicators of these messages need to take an account of this and maximize the benefits to the individual so the individual can ascertain what to do. Based on this cost and reward platform, rational theory can help in leading persuasion to mitigate Covid-19. However, the theory has some challenges, for instance it does not account for intuitive behaviors. Issues of relating to survival and other emergencies will not permit the individual to make this cost and reward analysis, and the theory offers no justification for this. Again, the theory is too individualistic and gives little room to translate for larger groups, institutions and structures in society. The pandemic is affecting all aspects of the globe and therefore a broader perspective is needed in this regard.(Burns \& Roszkowska, 2016) In the accompanying paragraphs, the discussion is on how to ensure be it in groups or an individual that an intended message to towards the pandemic mitigation is successful.

\subsection{To what extent is persuasion effective?}

The word attitude has been utilized by social psychologists to denote individual's evaluation of any aspects of the world. (Olson \& Kendrick, 2008) Individuals have different reaction to a broad range of issues, topics, people and events among others. This implies different attitudes of people in different situations or different settings. For instance different individuals will have different attitudes to issues such as love, marriage, child birth, and sports among others. Personal or group beliefs may shape attitudes on the subjects mentioned above. Attitudes may influence our thought which might go a long way to influence how one behaves or acts in a given situation. 
People form attitudes through socialization and social learning, this means as individuals interact with others in the society they learn and pick up attitudes. This shapes our experiences and hence informs us to behave in certain ways at a particular time. For example a graduate student through interaction with his or her supervisor might pick up academic writing style and flair from the supervisor and this might influence how the student writes his or her academic materials.

It has been hypothesized by social influence researchers that information and normative actions are influenced by unique mechanisms that generate attitudinal changes. (Wood, 2000) An attitude is an individual's predisposition toward an object to be good or bad. Persuasion seeks to change this predisposition mainly through communication to what the message the communicator is communicating. In our world today, many news or information is in competition for attention. It is therefore not so new to adopt persuasive communication means to do some good in this times.

There are four elements that should be present in persuasive communication. These four elements include the source; which supposes who delivers the message, a target audience; which denotes who receives the message, the message and then some context in which the message was received. These elements to some extent addresses whether a persuasive communication will fail or succeed. Early researchers have studied how these elements aimed to change behaviour. A consideration of these elements and how it aided in handling issues when the Corona virus pandemic broke firstly are assessed below.

\subsubsection{Elements of Persuasion as techniques to fight Covid 19 pandemic}

The question 'Who says what and to whom and with what effect' was asked and guided by a persuasion research conducted by Hoveland, Janis and Kelly in 1953. (Hovland et al., 1953) This yielded a generous number of important findings which can be incorporated to how persuasion has been important during the initial outbreak of Covid 19 pandemic.

\subsubsection{Who says what? Source of Communication}

A communication typically has some source. It is the source that addresses or provides the message or information. The same message from two different sources can bring about different responses in audience. Credibility is central if any communicated message will fail or not. Any communication that comes from a source that seem to have mastery over the content he or she is presenting or sharing will be more successful than any communication from a source that seems to be lacking in expertise of the message being presented. A credible source is seen to be an expert or trustworthy. An expert refers to someone who has relevant and adequate knowledge or experience regarding a topic. So with corona virus pandemic experts who could be seen as credible by people include medical health practitioners and epidemiologists. People will pay more attention to them than for example lawyers and businessmen in these times. A trustworthy source may be seen as any source that seen to be lacking in ulterior motives and expresses honest opinion and judgment on the regarding topic. So here, religious leaders, social thinkers and some community leaders may be deemed to be credible by some people. Hence they communicate a message the people will be more accepting of this message than from other sources. Interestingly, with the outbreak of Covid-19, the World Health Organization deemed to be the main voice of health issues worldwide (an expert) coming out to declare that the disease which was initially considered to be an epidemic in China was now a pandemic brought some about of seriousness in governments and people worldwide. At this call, governments around the world irrespective whether they have recorded high numbers of Covid 19 cases or not or the pandemic has not reached their shores yet at all, were securing their shores and putting down drastic measures to address the pandemic. This communicated message was successful in persuading nations to take precaution because overtime The World Health Organization has been reputable with its research and findings on health issue. Hence an issue communicated by them is deemed credibly, so making those communicated to, heeding and acting on its message. Again when governments around the globe had initiated and implemented lock down measures, closing down public spaces such as schools, churches, clubs and some shops down among others there were many broadcasts seen with health representatives from frontline health workers with sullen faces employing the lane individual who is well to stay home because that is the only way the disease will stop moving. The credibility that the masses have in health workers made most people heeds to this caution and abided by the message being communicated. Also, religious leaders who were seen as trustworthy by their members complied with lockdown of their churches and religious spaces and urged members to collaborate with government precautions. People adhered because they regard such persons to be trustworthy.

Consequently, communicated message is most likely to be deemed successful if the audience realizes that the message being communicated by the source is free from their personal stake or interest. (Eagly et al., 1981) The messages communicated by health representatives across the world on the corona virus disease did not show they had anything in their stake for instance that they intended to take all the fun for themselves as the others stayed home. There it can be agreed that the use of health workers by various governments to communicate the importance of abiding by each and every protocol demanded by the covid-19 resulted in great successes across many nations. (ITV News, 2020) In the same sense, in the United States there was communicated message by public health officials that things were under control which made people paint that the pandemic was not so serious hence resulted in minimum adherence to lockdown measures which made situations to aggravate. (Sandman, 2020) Government 
executives around the world edged their people to stay home and not concern themselves with moving about as life matter. In Ghana, the president Nana Addo Dnakwah Akuffo addo was captured to have said in a statement to address his nation that "We know how to work and bring up the economy but we do not know how to bring lives lost back; so please stay home". (Peat, 2020) This sort of messages painted to the masses that the lockdown was rather in their interest.

Further, more physically attractive communicators are more likely to be successful than less attractive communicators. (Hovland \& Weiss, 1951) Most audience is more likely to be persuaded by audiences they feel are more attractive and hence they like than those they do not because they are not so attractive. This technique was also used. There were visual advertisements of attractive people of attractive working class, and ages who were wearing their nose mask and hence imploring other individuals to wear their mask and continue to keep it on when they were outside. Some stars such as musicians, actors and actresses among others were seen sanitizing their hands on set, washing their hands, greeting with their elbows and hence presenting that the masses follow up that style. People were urged on to move with alcohol based sanitizers, nose mass and observing social distancing among others due to this.

\subsubsection{What is said? Content of communication}

The informational content of what is being communicated is also meaningful if there can be any persuasion to inform attitudinal change. In addition to credibility and efforts of the communicator, there is considerable account given to the message being presented. Social psychologists have embarked on considerable amount of research to determine the effect of fear appeal messages. It was brought up that messages that are intended to arouse the feeling or emotion of fear in audience or that tend to threaten the audience most, resulted in least chance of audience accepting the message. However, mildfear inducing messages showed great numbers of acceptance and change. That is to say when people feel too threatened by a message, they intend to argue against and dismiss any chance that it can apply to them. (Liberman \& Chaiken, 1992) Especially on changing people's health-related behaviors, the use of extreme fear messages is not effective. (De Hoog et al., 2007) In application, most advertisement that has been circulating since the pandemic broke has had some amount of fear but not too extreme just enough to get the attention of the masses that although the disease is perilous, should they heed the necessary protocols being outlined by various health and government bodies, then it will be under control. So the individual could hope under the strenuous circumstance. There were many circulating jargons which preached "this too shall pass". Research findings have brought into light that health messages if framed in a manner where it seem hopeful or positive other than negative, it becomes more successful. (Rhodes, 2017) Here, the messages should attach an appeal of how the fearful effect could be avoided, other than leaving it at just the harm to come. For instance, a positive message in this light as "Stay home, stay safe" "Wear your nose mask when going out, lets kick corona out" would be more effective than negative messages as "If you out you'll shorten your life" or "If you do not wear your mask you'll weaken yourself and kill yourself'. The positively framed message will be more effective than the fear notices. Using fear appeals messages will be successfully when an advice is given at the end.

Again, messages that seem to be free from initiating any change in behavior in an individual are also more successful than others that are designed in a way that it seem to seek out to change an individual's behavior or attitude. (Walster \& Festinger, 1962) This approach is too often used by marketers and sales people. This makes people feel they are solely making the choice to pick up an attitude or a behavior and they are using their best judgment and what they are doing is right for them.

\subsubsection{To whom? The Audience}

Most individuals hardly like being told what to do or how to act and hence build a strong resistance around their freedom to decide for themselves. This makes the audience who implies the target receiver of persuasive messages very important. It is therefore necessary to know the audience. Audience comes in different ages, and this makes a lot of difference in how a message will be accepted. Audience may also comprise of people who are more logically than others and more emotional than others. People's feelings at a particular time are also essential in affecting if a persuasive message will go well or not. Therefore, in organizing and planning messages, good communicators try to anticipate the response of their audience. Further, make an argument into what will trigger a counter argument. Governments around the world encountered many debates on whether the disease was a scam or not. This issue was cleared when top health offices were used to communicate to the people. The declaration of the World Health Organization also brought things into perspective. Many governments adopted both modern and conservative methods to communicate to their audience from a range of background when they were initiating lockdown measure. When closing down churches and other religious home, reputable people from various religions were used to communicate to their members as to why they should stay home. During the Easter, St Basilica at the Vatican shut its doors and only Pope Francis possessed into the empty room to give Easter message. (CBS news, 2020) This is to relate to the audience who may be religious inclined both logic and emotions about the seriousness of the disease and the need to stay home. Also there were various advertisements of health workers across the globe joining to tell individuals to stay home showing footage of how serious things were at the various health centers. (ITV News, 2020) This went a long way to deter people from using a counterargument and staying home. Some audience tend to favor reasoned arguments, cognitive feedback hence goes in for reasoned debates. Some audience may just settle or communicators' attractiveness and ability to arouse their emotions and initiate sentimental 
reaction. When communicators take time to know their audience then they can come out with better arguments to make persuasive messages more successful.

\subsubsection{With what effect? Means of communication}

The channel or medium through which the information or message is communicated also counts and matters. Some channels or medium that can be used for persuasive messages include documents, magazines, sign board, bill boards, social media platforms, face to face appeals and the use of radio and television. These mediums are very important in the persuasion process. Most audiences are more tunes to use one of these mediums than others. For instance a youth may prepare what is served on any social media platform than listening to the radio. In application, the Covid 19 was no respecter of persons and sought to devour any person, hence all people forms target population who needed to be served with necessary information. Hence most governments employed mediums that could serve large population at the same time. Also, because people were being advised not to go out but stay indoors, the television, radio and online social media platforms were more incorporated than face to face appeals and big sign boards and bill boards. However, the medium of sin and bill boards were not completely ruled out.

The introduction of the internet and social media today has been very effective and useful in these times to communicate what is at stake to members even as people were required to stay home. For example in Ghana, President Nana Addo Dankwah Akufu Addo sought to give life telecast on the state of the nation regarding Corona virus disease. He used this medium to communicate to citizens on important issues such as number of active cases, numbers of recoveries, death cases and further steps to be taken. This guided Ghanaian citizens to be abreast current time and hence sought to follow up on all stated initiatives. Such medium or channel of communication makes it more understandable to target audience and hence makes persuasive communication more successful. Table 1 below, summarizes the four elements of persuasion and under what circumstances they will fail or not and ways used in addressing Covid 19.

\begin{tabular}{|c|c|c|c|}
\hline Elements of Persuasion & Guided to be successful & Result in failure & Application to Corona virus pandemic \\
\hline $\begin{array}{l}\text { 1. Source of Communication } \\
\text { (Who says what) }\end{array}$ & $\begin{array}{l}\text { i) Credible source } \\
\text { ii) Trustworthy source } \\
\text { iii) More attractive communicators }\end{array}$ & $\begin{array}{l}\text { i)Non- expert source } \\
\text { ii) Suspicious source } \\
\text { iii) Less attractive communicators }\end{array}$ & $\begin{array}{l}\text { i)Use of health worker and health } \\
\text { bodies both local and worldwide level } \\
\text { ii) Communiqués from World Health } \\
\text { Organizations } \\
\text { iii) Advertisements using frontline } \\
\text { health workers } \\
\text { iv) Involvement of honored } \\
\text { stakeholders by the masses such as } \\
\text { religious leaders. } \\
\text { v) Advertisements using renowned } \\
\text { movie stars and musician on } \\
\text { communicating Covid } 19 \text { precautions }\end{array}$ \\
\hline $\begin{array}{l}\text { 2. Content of message (what } \\
\text { is said) }\end{array}$ & $\begin{array}{l}\text { i) Minimum fear appeals } \\
\text { ii) Hope oriented } \\
\text { contents } \\
\text { iii) Advice on how effects can be } \\
\text { avoided } \\
\text { iv) Free coercion }\end{array}$ & $\begin{array}{l}\text { i) Extreme fear induced messages } \\
\text { ii) Negative communicated messages } \\
\text { iii) Use of coercive words and } \\
\text { expressions }\end{array}$ & $\begin{array}{l}\text { i)Communicating evidence on } \\
\text { effectiveness of Covid } 19 \text { protocols } \\
\text { such as isolation and quarantine on } \\
\text { cases } \\
\text { ii) Abiding by Covid } 19 \text { protocols will } \\
\text { subdue the disease }\end{array}$ \\
\hline $\begin{array}{l}\text { 4. Means of communication } \\
\text { (with what effect) }\end{array}$ & $\begin{array}{l}\text { i) Modern online means (social media } \\
\text { platforms) } \\
\text { ii) Conventional platforms } \\
\text { ( billboards, radio broadcast, face-to- } \\
\text { face appeals) }\end{array}$ & $\begin{array}{l}\text { i)Using unvaried } \\
\text { communication }\end{array}$ & $\begin{array}{l}\text { i) Advertisement on online platforms } \\
\text { and social medias } \\
\text { ii) Complementing all other means of } \\
\text { broadcast such as sign boards, radio's, } \\
\text { telecast among others }\end{array}$ \\
\hline
\end{tabular}

Table 1

As nations around the world are easing and relaxing lockdown measures, it was easy to channel what is expected of people using these mediums. In late December, 2020, few countries such as Italy and Germany banned Christmas festive activities, and initiated harsh lockdown measures (Chadwick, 2020)(Welle, n.d.) By the closing of 2020 year many countries were steadily easing down lockdown measures although other protocols such as wearing of nose mask, social distancing, washing of hand and sanitizing with alcohol based sanitizer. Some public gatherings spaces such as churches, mosques, restaurants among others were gradually being opened. Some countries also opened their borders to people 
from other countries again. Yet still, the deadly disease has not been completely knocked out. Some individuals because things are gradually being ease down want to all quickly return to their previous way of life, and gradually neglecting some of the protocols. This call for putting adequate measures in place to arrest such situation to get people to still abide by basic Covid 19 protocols such as mandatory wearing $f$ the nose masking, maintaining social distancing among others, in order to prevent a destructive break of the pandemic again.

\subsection{Fostering Adherence to Covid-19 Precautions}

In world history, there has been a common pattern identified with other pandemics when they hit the world. There would be waves of cases which when they hit becomes more perilous and claim more lives. The 1918 pandemic which was known as the Spanish Flu hit the world in three waves. With the succeeding waves being deadly and killing more precious lives. (Roos, 2020) The Russian Flu pandemic which also preceded the Spanish had succeeding waves which was also deadly. (Phillips, 2020) Historians have reviewed that the Spanish Flu especially fatal and severe in the second wave. Experts wonder and anticipate if the corona virus disease will have waves like previous pandemic. Other health officials and epidemiologists have speculated a second wave and believe this will be more severe.

Nevertheless, it should not be overlooked that if there is to be more powerful waves to hit our world again then human behavior and attitudes will be the main determinant. When the disease broke initially, due to the anxiety, fear and panic it came with governments and health officials around the world took time to communicate precautionary measures which should be followed to arrest the situation. This led to introduction of governments around the world locking their borders to other countries. Also, there have been bans on public gatherings and further shutting of public spaces of gatherings such as churches, schools, mosques, clubs, and night clubs among others. There was also mandatory initiation of precautionary measures such as wearing of nose mask when going out, isolation, quarantine, social distancing, and washing of hands and usage of hand sanitizer. This gave a new sphere to the world and left majority of the world interaction in virtual community.

Besides, these were tough times in history of mankind. There were many messages from policy makers, stakeholders, health experts and media to carry the world through. In recent times, countries around the world are easing down strict lockdown measures. The economy was one sector that struggled due to some of these measures. In recent times, some countries that closed their airports to disallow any travels in to the country have began to open up to allow travels as strict precautions such as wearing of nose mask, hand washing among others persist. Some have also allowed for some spiritual gatherings such as churches to be opened once again. Some also are opening schools and other public places with condition being adherence to strict corona virus precaution as wearing of nose mask through interaction, and practicing social distancing among others. This has made things a little bit flexible in the midst of other restrictions.

Again, there have been introduction of corona virus vaccines to foster herd immunity. Some countries are giving out these vaccines to their people in a step to combat the notorious corona virus disease. However, there has not been any formal documentation to a cure to the virus or any statement on the corona virus disease being no longer a pandemic. There is still some news on how deadly it is. The India recent challenge on how there are grave numbers of corona virus cases each day currently shows the pandemic is still hovering around us. However, because some measures have been made flexible some people all too soon want to go back to their previous normal and tend to avoid existing mandatory corona virus precautions. Some people have had issues with the government for not wearing their nose mask among others. Interesting, the stakes have been clear, places where Covid-19 protocols tend to be violated tend to have higher cases. This shows that identified measures has to quickly be put in place to first and most importantly tackle human attitudes and behaviors in these times to abide by corona virus disease precautions. This is because when people change their behavior to tune with precautionary measures outlined by experts then the virus can be conquered.

Seeking to change human behavior can be fostered by persuasive communications as have been discussed above. This paper further seeks to use persuasive theories to align and show how effective persuasive communication can be employed to help change human behaviors at this time. Social psychology has a number of persuasive theories which can be tapped into to solve this mystery. A theory can be referred to as a blueprint which can be used to explain or applied to different interactions. It is a testable logic. (Allan, 2010) The following social psychological theories of persuasion are analyzed and its application to changing human behaviors at this time is discussed. Three theories are considered in this regard which include Social Judgment Theory, Conflict Dissonance Theory and Elaboration Likelihood Theory.

\subsubsection{Social Judgment Theory}

The social judgment theory was postulated by Muzafer Sherif and Carl Hovland, and then later received contributions from Carolyn Sherif. This framework analyzes and studies types of communication messages and under what circumstances this will lead to human behavioral change. (Sherif \& Hovland, 1961) This dwells on individual judgment technique. In essence, they found out that people's perception in relation to beliefs, attitudes, behaviors and values exists on a continuum. This is represented on three latitudes including latitude of rejection, latitude of non-commitment and latitude of acceptance. On the latitude of judgments, the latitude of rejection refers to an individual judgment against as not conforming to the propagated desired behavior. The latitude of non-commitment involves is the middle, people might not 
wholly embrace but partially adopt it holding unto some conditions. The latitude of acceptance denotes full acceptance of desired behavior. Sherif and Hovland found out that when persuasive messages fall into an individual's latitude of acceptance then they are more likely to be successful. In illustration, when sending persuading message to the masses to still adhere to social distancing protocols, some may disagree outright with the mindset that it is no longer necessary; these are on the latitude of rejection, others may think to agree to the terms believing the disease is still deadly; these are on the latitude of acceptance, still others might agree and follow some precautions like wearing of the mask but when asked not to visit and hug friends and loved ones they will object; these are on the latitude of non-commitment. Their theory proposes persuading people who agrees with one's opinion.

In a reality, it is necessary to persuade people who do not accept messages being propagated hence to help us to persuade people who are not in acceptance to the message; first communicators have to consider the range of diverse beliefs, values, and attitudes of people. According to Sherif and Hovland theory, persuasion will be effective if one knows the range of discrepancy between a communicator's viewpoint and the audience viewpoint. Persuasive messages will be more effective if the speakers' view and the audience view are the same. However, if there is a wide gap then persuasion will fail. In application to our reality, it is known that some people are on the latitude of rejection concerning messages employing people to adhere to corona virus disease precautionary measures. Firstly if any meaningful work can be done to address this, communicators and speakers have to send out messages that will bridge this gap and get people on a level where they are ready to accept precautionary messages. This can be achieved if health experts and leaders of government broadcasts clearly on the woes at hand showing the number of cases which is increasing as a result of the irresponsible behaviors not to abide by Covid-19 protocols. The corona virus is spread through contact, anytime there are active cases which was spread through contact tracing, this should be communicated for persons to come to know that the virus is still active and the pandemic has not been completely defeated. This will raise audience latitude to acceptance; there will be no gap between communicators and audiences hence persuasive messages when communicated becomes more successful and effective. Also, as already mentioned that audience are more likely to change behaviors when they see hope or positivity, it should also be broadcasted to show how adherence to precautionary measures is positive and can lead the world against the pandemic.

\subsubsection{Cognitive Dissonance Theory}

This theory was formulated by Loen Festinger, who was an American social psychologist best known for his cognitive dissonance theory and social comparison theory. Festinger's cognitive dissonance theory proposes that when an individual entertains two or more contradictory attitudes, beliefs or behaviors a state of inconsistency arises which causes the individual to be in an uncomfortable psychological state. This demands an individual to change one of the inconsistent elements to reduce the dissonance.(Festinger, 1957) The goal of persuasive communication here is to accelerate enough dissonance in audience in a way that they will seek to change behavior, attitude or values to the desired. For example, airports have been opened and so allow individuals to travel to meet loved ones, however there is still social distancing and wearing of nose mask precautions that one has to adhere to. Social distancing calls against people hugging, handshaking and people coming into very close contact with others. People who have not seen their friends or family will like to share a hug. This puts an individual in cognitive dissonance.

On how to address cognitive dissonance, Frymier \& Nadler asserted that, three conditions have to be considered. These include aversive consequences, freedom of choice and insufficient external justification. (Frymier \& Nadler, 2007) Aversive consequences denote that for cognitive dissonance to work there should be existence of strong consequences or punishments for individuals who do not change their behaviors or attitudes. In application, an aversive consequence for persons caught not wearing their nose mask in these times could be prosecution before court which will merit time in jail or paying huge fines. This will be more effective than when people are left with the consequence of mere warnings. When few people are put through these for a while a great majority will begin to comply by persuasive messages. Aversive consequence states the punishment should be harsh enough hence this can be employed by governments to save the situation at hand. The freedom of choice is the second necessary condition and this denotes that audience should have a free will to choose and make decisions; the audience should not be coerced. This is because, if audience have the feeling that they are not being coerced then they will freely accept persuasive messages which will make persuasion effective and successful. To increase cognitive dissonance, speakers or communicator's needed to make sure their audience have the feeling that they are not being manipulated or coerced. By this, clear communication from governments, stakeholders and health experts will make people become abreast with current state of affairs as far as corona virus disease is concerned. This will make individuals have at their disposal facts on the disease and be able to decide for themselves whether adherence to precautions is key are they are just being scammed. Clear and adequate communication from credible sources will also present proper information on why governments can now ease some measures and still call for adherence to few others. The audience imaginations of audience will be sharpened and this can be used to make decisions and change behaviors in line to persuasive messages being communicated.

The last condition identified for cognitive dissonance to work has to do with insufficient external justification. This implies the presence of two things which are external and internal justification. External justification has to do with an individual 
identifying reason outside of one's power to foster belief, attitude or behavior change. Internal justification has to do with individuals own reason from within to change a behavior or attitude to reduce cognitive dissonance. (Festinger \& Carlsmith, 1959) In application, messages that speak to people's intrinsic judgment of themselves can be used to create dissonance for them to change their behaviors. As an illustration, advertisements can use the line of "If you think you are a responsible adult or person, wear your nose mask". Also, "if your family matters to you stay home and don't host any party home which will invite corona virus to your home". These messages speak to the conscience of people and hence they will have insufficient external justification but broader internal justification which will induce dissonance for them to change because of their own voluntarily assessment of themselves. They believe they are changing for themselves and hence adopt persuasive messages.

\subsubsection{Elaboration Likelihood Theory}

The final theory to be discussed in this discourse is the Elaboration Likelihood Theory. Social psychologists found that not only are people being persuaded through active effort thought, but sometimes people get to be persuaded and change their attitude when they are not thinking hard on the information at all. People may tend to make a decision to change using efforts that requires less cognitive processing such as how attractive a communicator is or how nice the presentation looked. These different ideas were represented in Richard Petty and John Cacioppo's elaboration likelihood theory. They formulated that effortful and non-effortful processes can institute attitude or behavior change in an individual. (Petty \& Cacioppo, 1960)

From the view of Richard Petty and John Cacioppo in their theory, elaboration refers to the amount of cognitive effort or thought an individual uses to analyze content of a message.(Petty \& Cacioppo, 1960) They explained this in terms of high elaboration and low elaboration. High elaboration uses cognitive energy to screen and analyze arguments within a message or the content of a message. This employs the central route for examining. On the other hand, low elaboration does not use cognitive energy or effort for analyzing contents of any message. The peripheral route is used. This enlightens that in any audience there will be a group of people who will employ the central route to examine the meaningfulness of whatever is being communicated. Hence, it is important to raise some strong undisputable arguments for this category of people. Also, part of the audience will be processing through the peripheral route and hence apart from the arguments of the message care should be taken to address all issues that can meet the attention of this group of people. For instance, in a television advert on why one should wash the hand frequently during these times; the advert can argue on advantages and disadvantages of hand washing in detail and also make sure actors in the advert look neat, attractive and sound well among others. It is not surprising that many adverts uses models, movie and music stars to sell their message.

Further, Petty and Cacioppo opined that, how people choose one route or the other is dwelled on two factors. The first is ability; this explains how the audiences are able to process the message by comprehending it without complication. The language of the message should not be too complicated. For example, in West Africa countries have their official language to be either English or French. However, the natives have their common dialect they speak and easily interact and understand. Should a government or health experts here only deploy messages on the pandemic in an Official language which cannot be well understood by natives, persuasion here will fail because people will not process message through the central route and may not pay attention to it at all. The message will become too complicated for them. The second factor is motivation. This refers to if the audience chooses to regard the message and reflect on its details. As a result of personal relevance, personal responsibility, personal need for cognition, personal involvement in what is being communicated. (Frymier \& Nadler, 2007) In application, when communicators are sending messages to the masses to continue to abide by Covid 19 precautions, they can add in their message, state of affairs on the pandemic in their jurisdiction, for people to be able to well relate other than the broad international outlook of the pandemic. Although, world statistics can be communicated, statistics on increase in cases currently in the audience location should be communicated, with details on death cases, recovery cases, and rate of infection among others. This will enable the audience to have an inward motivation to heed persuasive message.

Table 2 below briefly expatiate crucial points of the three discussed theories for policy implementations to deal with the pandemic.

\begin{tabular}{|c|c|l|}
\hline Persuasion Theories & Key points & $\begin{array}{c}\text { Relevance to policy implementation to deal } \\
\text { with pandemic }\end{array}$ \\
\hline Social Judgment Theory & $\begin{array}{c}\text { Beliefs and values of people that puts their } \\
\text { judgment on latitude of rejection, latitude of } \\
\text { acceptance and latitude of non-commitment to } \\
\text { messages being propagated }\end{array}$ & $\begin{array}{l}\text { i) Communicate facts of the pandemic; } \\
\text { provide clear evidence on stakes at hand to } \\
\text { make people see the seriousness of the issue, } \\
\text { hence be at the point of accepting. }\end{array}$ \\
\hline Cognitive Dissonance Theory & $\begin{array}{l}\text { Create enough dissonance in audience } \\
\text { mindset to stimulate behavior changes }\end{array}$ & $\begin{array}{l}\text { i)Policy makers should initiate harsh } \\
\text { punishments to persons found who go } \\
\text { contrary to Covid 19 protocols } \\
\text { ii) Current state of affairs regarding the } \\
\text { pandemic should be discharged openly with }\end{array}$ \\
\hline
\end{tabular}




\begin{tabular}{|c|c|c|}
\hline & & $\begin{array}{l}\text { clear sources for people to monitor number of } \\
\text { active cases, recovery cases and deaths. } \\
\text { Frontline health workers should champion } \\
\text { this } \\
\text { iii) Usage messages that will speak to } \\
\text { individual conscience }\end{array}$ \\
\hline Elaboration Likelihood Theory & $\begin{array}{l}\text { Usage of messages and languages audiences } \\
\text { can understand and better relate to, } \\
\text { Use arguments and communicators that } \\
\text { audience can relate to, to think carefully and } \\
\text { follow propagated message }\end{array}$ & $\begin{array}{l}\text { i) Various adverts should be in local dialects in } \\
\text { nations where natives have diverse languages } \\
\text { ii) The lay man should have a shared } \\
\text { responsibility in making things better. } \\
\text { For instances, families as the main socializing } \\
\text { agents, can be involve to re-socialize their } \\
\text { members in collaborating with outlined } \\
\text { pandemic precautions }\end{array}$ \\
\hline
\end{tabular}

Table 2

\section{DISCUSSION}

This paper has considered the involvement of the social psychology discipline in mitigating corona virus pandemic. Social psychologists consider persuasion as a means to use targeted communication to derive behavioral and attitudinal change in people. The corona virus disease brought tremendous changes making re-socialization of people of the world necessary in order to salvage the situation. The paper discussed how elements of persuasion such as communicator, audience, message and means of communication should be aligned properly for any persuasive message to be successive. Some adverts as should frequently whether directly or indirectly, knowing or unknowingly has captured these techniques and have been successful. However, with the current turnaround and the easing down of some Covid 19 measures, most people want to go back quickly to their previous ways of life and this is not safe because it can trigger another harsh wave of the pandemic. Nonetheless, the paper has discussed some tangible theories on persuasion which can be applied to check this. Then further introduced a direction into the future, a world with no Covid 19 and how persuasive message can assist in countermeasures against any problems which may arise. Persuasive messages can be dispatched by stakeholders in society to communicate clearly to people to motivate and prepare them for a life where you do not have to wear a nose mask compulsory when going out, where people can interact freely once again. Humans are social and emotional being and to be able to create positive attitude in them good persuasive techniques must be employed.

\section{CONCLUSION}

Persuasion is instrumental in shaping and forming behaviors. As an interested in understanding of how individual behaviors are formed and shaped in this crucial time, the discourse has provided insights into factors that account for influence on people's behavior in this pandemic. Various discussions of some persuasion theories and techniques have been discussed into details with how it can be applied. The rational choice theory is a social science theory that seeks to explain what factors influence individual decision in making choices. The scope has discussed the rational choice theory and sees how its strengths can be tapped in mitigating the pandemic. Future and further research can venture into how people build reactance or resist persuasion and what causes or influences people to actively defend their behaviors and attitude.

Just as all previous pandemics that have hit the world have been subdued at some point in the history of our world, experts in all fields are trying their efforts in mitigating the Covid-19 as well. Therefore, it is timely for stakeholders, policy makers and social thinkers to start mapping out blueprints on how to prepare our world for a life beyond Corona virus pandemic. All persons are different and have different ways of dealing with struggle, the pandemic has brought its own burden, and people will need assistance in returning back to their regular life. Future research can look at what factors will be responsible for enabling individuals, families, businesses and communities live in a world beyond the pandemic.

\section{REFERENCES}

[1] Allan, K. D. (2010). Contemporary Social and Sociological Theory: Visualizing Social Worlds. Books.Google.Co.Uk.

[2] Bavel, J. J. Van, Baicker, K., Boggio, P. S., Capraro, V., Cichocka, A., Cikara, M., Crockett, M. J., Crum, A. J., Douglas, K. M., Druckman, J. N., Drury, J., Dube, O., Ellemers, N., Finkel, E. J., Fowler, J. H., Gelfand, M., Han, S., Haslam, S. A., Jetten, J., ... Weeden, K. A. (2020). COVID-19 pandemic response. Nature Human Behaviour, 4(May), 1-12. http://dx.doi.org/10.1038/s41562-020-0884-z

[3] Burns, T., \& Roszkowska, E. (2016). Rational Choice Theory: Toward a Psychological, Social, and Material Contextualization of Human Choice Behavior. Scientific Research Publishing.

[4] Campbell, H. A. (2020). Religion in Quarantine. www.digitalreligion.tamu.edu

[5] CBS news. (2020). Pope Francis celebrates joy of Easter amid sorrow of coronavirus pandemic. https://www.cbsnews.com/news/pope-francis-easter-sunday-massvatican-coronavirus-pandemic/

[6] Chadwick, L. (2020). Italy bans Christmas travel and midnight mass after nearly 1,000 people die in one day. 2020. https://www.euronews.com/2020/12/03/europe-not-in-a-stablesituation-says-who-as-cases-rise-in-serbia-and-croatia

[7] De Hoog, N., Stroebe, W., \& de Wit, J. B. F. (2007). The impact of vulnerability to and severity of a health risk on processing and acceptance of fear-arousing communications: A meta-analysis. Review of General Psychology,. A Meta-Analysis. Review of General Psychology, 11, 258-285.

[8] DImaio, D., Enquist, L. W., \& Dermody, T. S. (2020). A New Coronavirus Emerges, This Time Causing a Pandemic. Annual Review of Virology, 7, iii-v. https://doi.org/10.1146/annurev-vi07-042020-100001 
[9] Eagly, A. H., Chaiken, S., \& Wood, W. (1981). An attributional analysis of persuasion. Hillsdale, NJ: Lawrence Erlbaum.

[10] Festinger, L. (1957). A theory of cognitive dissonance. Evanston, IL: Row, Peterson, \& Company.

[11] Festinger, L., \& Carlsmith, J. M. (1959). Cognitive consequences of forced compliance. Journal of Abnormal and Social Psychology, 58, 203-210.

[12] Frymier, A. B., \& Nadler, J. K. (2007). Persuasion: Integrating theory, research, and practice. Dubuque, IA: Kendall/Hunt.

[13] Harvard Magazine. (2013). The Politics Of America's Fight against Global Warming. https://scholars.org/features/politicsamericas-fight-against-global-warming

[14] Hovland, C. I., Janis, I. L., \& Kelley, H. H. (1953). Communication and persuasion: Psychological studies of opinion change. New Haven, CT: Yale University Press.

[15] Hovland, C. I., \& Weiss, W. (1951). The influence of source credibility on communication effectiveness. Public Opinion Quarterly.

[16] ITV News. (2020). Government launches new coronavirus advert with stay at home or "people will die" message. https://www.itv.com/news/2020-04-02/stay-at-home-or-peoplewill-die-government-launches-new-coronavirus-ad-blitz

[17] Liberman, A., \& Chaiken, S. (1992). Defensive processing of personally relevant health messages. Personality and Social Psychology Bulletin.

[18] Olson, M. A., \& Kendrick, R. V. (2008). Origins of attitudes. New York: Psychology Press.

[19] Peat, J. (2020). President of Ghana provides much-needed perspective in these troubling times. https://www.thelondoneconomic.com/politics/president-of-ghanaprovides-much-needed-perspective-in-these-troubling-times182624/

[20] Perloff, R. (2003). The dynamics of persuasion: Communication and attitudes in the 21st Century. In Mahwah, NJ: Lawrence Erlbaum, pp. 5-6.

[21] Petty, R. E., \& Cacioppo, J. (1960). Communication and persuasion: central and peripheral routes to attitude change. Advances in Experimental Social Psychology, 19, 123-205.

[22] Phillips, H. (2020). '17, '18, '19: Religion and science in three pandemics, 1817, 1918, and 2019. Journal of Global History, 15(3), 434-443. https://doi.org/10.1017/S1740022820000315

[23] Rhodes, N. (2017). Fear-Appeal Messages: Message Processing and Affective Attitudes. Communication Research, 44(7), 952975. https://doi.org/10.1177/0093650214565916

[24] Roos, D. (2020). Why the Second Wave of the 1918 Flu Pandemic Was So Deadly. 1-13.

[25] Saldaña, J. (2013). The coding manual for qualitative researchers [Kindle edition]. In Retrieved from: Amazon. com.

[26] Sandman, P. M. (2020, August 24). Commentary: Public health's share of the blame: US COVID-19 risk communication failures | CIDRAP. https://www.cidrap.umn.edu/newsperspective/2020/08/commentary-public-healths-share-blame-uscovid-19-risk-communication

[27] Sherif, M., \& Hovland, C. (1961). Social judgment: Assimilation and contrast effects in communication and attitude change. New Haven, CT: Yale University Press.

[28] Walster, E., \& Festinger, L. (1962). The effectiveness of "overheard" persuasive communication. Journal of Abnormal and Social Psychology, 65, 395-402.

[29] Welle, D. (n.d.). Germany: Calls grow for harder lockdown ahead of Christmas holidays. In 2020. https://www.dw.com/en/germany-calls-grow-for-harderlockdown-ahead-of-christmas-holidays/a-55871593

[30] Wood, W. (2000). Attitude change: persuasion and social influence. Annual Review of Psychology, 51, 539-570. https://doi.org/10.1146/annurev.psych.51.1.539 